\title{
PENGARUH PEMBIAYAAN MUDHARABAH DAN MUSYARAKAH TERHADAP PROFITABILITAS
}

\author{
Paisal Muhamad Fikri \\ Universitas Singaperbangsa Karawang \\ paisalmuhamadfikri@gmail.com \\ Wirman \\ Universitas Singaperbangsa Karawang \\ wirman@feb.unsika.ac.id
}

\begin{abstract}
ABSTRAK
In this research, we want to know the effect of mudarabah and musharakah financing on the profitability (ROA) of Bank Muamalat Indonesia. In this case the author uses quantitative methods and the type of data in this study is secondary data in the form of time-series. The population used is a quarterly financial report at Bank Muamalat Indonesia for the period 2012-2019 where the total is 32 financial reports for 8 years. The sample selection uses a saturated sample where all of the population is sampled. The findings show that: (1) Mudharabah financing has a positive and significant effect on profitability (ROA). Proven by sig. $0.014<0.05 \mathrm{t}$ count $2.617>\mathrm{t}$ table 2.042. (2) Musharakah financing has a negative and significant effect on profitability (ROA). Proven by sig. $0.000<0.05$ t count $-7.102>$ t table 2.042.
\end{abstract}

Kata Kunci: Mudharabah, Musyarakah, Profitabilitas (ROA)

\section{PENDAHULUAN}

Bank syariah pada saat ini mengalami perkembangan yang sangat cepat. Dikarenakan masyarakat Indonesia sebagian besar memluk agam islam, maka masyarakat lebih tertarik terhadap kegiatan perbankan yang tidak memiliki riba yang saat ini berkaitan dengan bank konvensional. Inilah yang membangun masyarakat memilih syariah sebagai bentuk pembiayaannya. Tidak hanya yang memeluk islam saja yang memilih nya, Hal tersebut terjadi karena melahirkan tindakan perbankan yang mempermudah klien.

Pemberian pembiayaan konvensional dan syariah pasti memiliki item yang berbeda. Konvensional melihat faktor dari bisnisnya apakah layak atau tidak, sedangkan syariah melihat yang dilakukannya harus sesuai dengan syariah islam. Bisnis yang akan dijalankan harus memenuhi kriteria syariah. Sejalan dengan kejadian di dunia perbankan kehadiran syariah tidak mesti dari faktor kuantiti nya saja, namun dari faktor nilai juga menjadi pertimbangan. Maka dari itu meningkatkan nilai dari perbankan khususnya syariah dapat menjadi daya tarik sendiri untuk mendapatkan kepercayaan dari klien. Dalam mengukur nilai tersebut, ditunjukkan oleh profitabilitas yang dihasilkan dari pembiayaannya.

Kehadiran syariah yang menerapkan proses pembagian keuntungan mudharabah dan musyarakah. Sebuah bank dinilai baik jika memiliki rasio keuangan, yang bisa dilihat dari profitabilitasnya. Rasio dari sebuah laporan keuangan yang menjadi alat untuk menjelaskan hubungan antara faktor tunggal dan lainnya, dimana rasio profitablitas yang menjadi salah satu hal yang paling utama. Profitabilitas memili arti yang penting dalam menjaga perusahaan untuk terus bertahan dalam waktu yang panjang, karena profitabilitas sebagai tampilan jika perusahaan memiliki pandangan yang baik di masa depan. Salah satu faktor dalam Pembiayaan syariah menjadi penentu dalam menentukan suatu tingkat laba di Bank Muamalat. Laba pada bank syariah 
tersebut dapat ditunjukkan oleh suatu profitabilitas yang pada dasarnya dapat diukur melalui rasio keuangan (Nawawi et al., 2018).

Rasio keuangan yang menjadi pengukur disini yaitu Return On Asset dimana rasio ini mengukur tingkat laba terhadap asset.

Menurut penelitian sebelumnya yaitu Teguh Arifianto dan Apollo (2020) menyatakan bahwa pembiayaan mudharabah berpengaruh positif dan signifikan terhadap profitablitas. Dan menurut penelitian Yentisna dan Alfin Alvian (2019) menyatakan bahwa pembiayaan musyarakah berpengaruh signifikan terhadap profitabilitas. Terjadi fenomena dimana pembiayaan mudharabah, musyarakh dan return on asset mengalami fluktuasi kenaikan dan penurunan setiap tahunnya. Berdasarkan fenomena yang terjadi maka peneliti menginginkan penelitian mengenai "Pengaruh Pembiayaan Mudharabah dan Musyarakah terhadap Profitabilitas".

\section{KAJIAN PUSTAKA DAN PENGEMBANGAN HIPOTESIS}

\section{Akuntansi Syariah}

Akuntansi syariah merupakan akuntansi yang sangat berkembang yang tidak hanya dalam "tambal sulam" yang kaitanya dengan konvensional tetapi merupakan evolusi filosofis dari nilai Al-quran yang telah diturunkan kedalam pemikiran konseptual dan teknologi akuntansi (Arwani, 2016:273).

\section{Pembiayaan Mudharabah}

Pembiayaan mudharabah adalah salah satu bentuk penyaluran dana yang dilakukan dalam suatu bank syariah untuk berbagai pihak dalam suatu usaha produktif dengan menggunakan akad mudharabah (Aulia, 2020:62). Disisi lain istilah Qiradh juga dikenal sebagai pembiayaan mudharabah. Qiradh merupakan kerja sama antara kedua belah pihak yang memiliki dana serta menyediakan modal, sedangkan pihak lain yang menjadi pihak kedua menjadi ataupun selaku pengelola dan keuntungan yang didapatkan dibagi sesuai dengan kesepakatan yang terjadi dalam kontrak yang dibuat (Subakti, 2019:2-3).

\section{Pembiayaan Musyarakah}

Musyarakah merupakan suatu pengaturan perjanjian kerja sama antara pihak-pihak terkait untuk suatu kegiatan usaha yang utama, masingmasing kelompok memberikan sarana berupa dana dan kesepakatan bersama bahwa manfaat serta bahaya yang ditimbulkan menjadi tanggung jawab bersama (Antonio, 2001:90)

Musyarakah juga dapat diartikan sebagai bentuk dalam melakukan kerja sama yang dilakukan oleh pihak terkait yang masing-masing berkontribusi atas sumber dana yang memiliki ketentuan dimana keuntungan dibagi dengan proporsional serta bahaya ataupun risiko yang kemungkinan terjadi ditanggung kedua pihak yang terkait (Hasanuddin \& Mubarok, 2012:82-83).

\section{Profitabilitas}

Profitabilitas yaitu suatu proporsi untuk menilai kemampuan perusahaan dalam menghasilkan laba pada tingkat penjualan, asset, modal saham tertentu (Kasmir, 2012:196).

Rasio profitabilitas merupakan pengukuran yang bertujuan untuk mengetahui sejauh mana perusahaan dapat menghasilkan keuntungan dalam suatu periode (Septiana, 2019:108).

Return On Asset dikenal juga sebagai Economic Profitability yang menjadi suatu ukuran dalam mengukur keuntungan terhadap seluruh asset yang digunakan dalam mendapatkan laba (Kariyoto, 2017:114).

\section{Pengaruh Pembiayaan Mudharabah terhadap Profitabilitas}

Akad mudharabah melakukan perjanjian dengan pihak-pihak yang terkait dalam menjalankan kerja sama, dalam akad mudharabah kontrak yang dilakukan bukan dari pemberi modal tetapi dari fasilitator dalam sumber dana (shahibul maal) dan yang mengelola atas dana tersebut (mudharib), dan jika menghasilkan keuntungan, keuntungan tersebut diberikan sesuai dengan perjanjian, namun jika terjadi bahaya atau risiko maka hal tersebut hanya dirasakan fasilitator sumber dana. Selain daripada hal tersebut, pembiayaan ini mempunyai kaitan yang positif terhadap profitabilitas. memiliki pengaruh positif 
terhadap profitabilitas, dikarenakan jika pembiayaan ini terus meningkat, hal tersebut akan membuat perusahaan mendapatkan keuntungan dari hasil pembiayaannya. (Dyah et al., 2017)

Teori yang telah dijelaskan di dukung oleh penelitian Muhammad Rizal Aditya (2016) dalam hasil penelitiannya, adanya pengaruh positif dan signifikan terhadap profitabilitas.

H1 : Adanya pengaruh positif dan signifikan

\section{Pengaruh Pembiayaan Musyarakah terhadap Profitabilitas}

Akad musyarakah melakukan kesepakatan dengan pihak-pihak terkait untuk mengumpulkan modal dalam menjalankan perusahaan. Kedua pihak atau lebih mempunyai hak nya menurut proporsi masing-masing sesuai atas modal yang mereka himpun serta memiliki hak mengawasi atas prporsinya masing-masing. Pembiayaan musyarakah memiliki pengaruh negatif terhadap profitabilitas, dikarenakan jika pembiayaan ini terus meningkat, hal tersebut dapat menurunkan profitabilitas.

Teori yang telah dijelaskan di dukung oleh penelitian. Faisal Umardani Hasibuan (2019) dalam hasil penelitiannya, adanya pengaruh negative dan signifikan terhadap profitabilitas.

$\mathrm{H} 2$ : Adanya pengaruh negatif dan signifikan

\section{METODOLOGI PENELITIAN Populasi dan Sampel}

Dalam hal ini penulis memakai metode kuantitatif dan Jenis data dalam penelitian ini adalah data sekunder dalam bentuk time-series. Populasi yang dipakai yaitu suatu laporan keuangan berdasarkan triwulan pada Bank Muamalat Indonesia periode 2012-2019 dimana total menjadi 32 laporan keuangan selama 8 tahun. Pemilihan sampel memakai sampel jenuh dimana semua yang menjadi populasi dijadikan sampel.

\section{Metode Analisis Data}

Metode analisis deskriptif yang dipakai dalam penelitian ini, yang merupakan wujud analisa yang menguji keseluruhan hasil dari suatu penelitian dengan menggunakan satu sampel (Siregar, 2017:100).

\section{HASIL PENELITIAN DAN PEMBAHASAN Deskriptif Statistik}

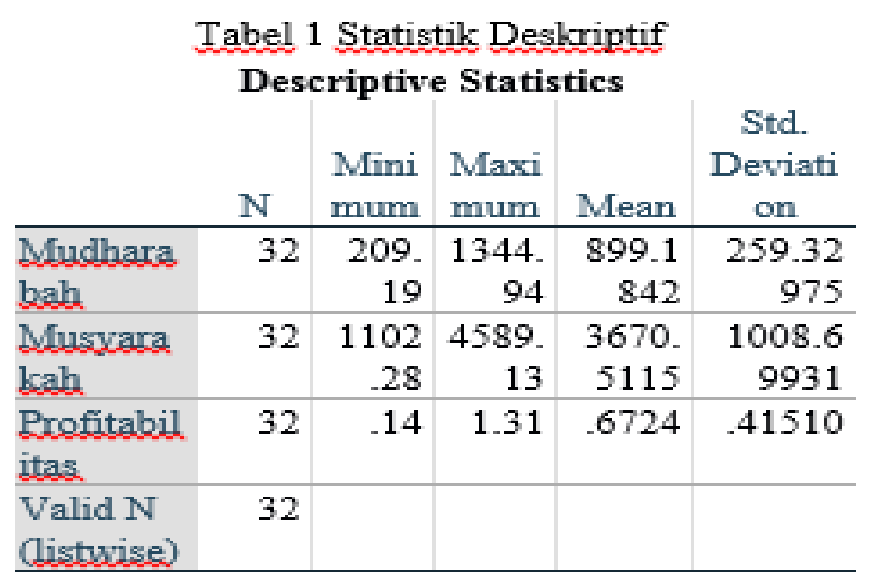

Tabel 1 diketahui terdapat 3 variabel yaitu pembiayaan mudharabah, musyarakah, ROA). Dengan jumlah sampel keseluruhan sebanyak 32 sampel. Penjelasan mengenai tabel diatas adalah sebagai berikut:
Berdasarkan hasil diatas bisa kita lihat bahwa variabel X1 memiliki mininimum 209,19 maximum 1344,94 mean 899,184 dan standar deviasi 259,32975. Variabel X2 memiliki minimum 1102,28 maximum 4589,13 mean 
3670,51 dan standar deviasi 1008,6993. Variabel 0,6724 dan standar deviasi 0,41510 .

Y memiliki minimum 0,14 maximum 1,31 mean

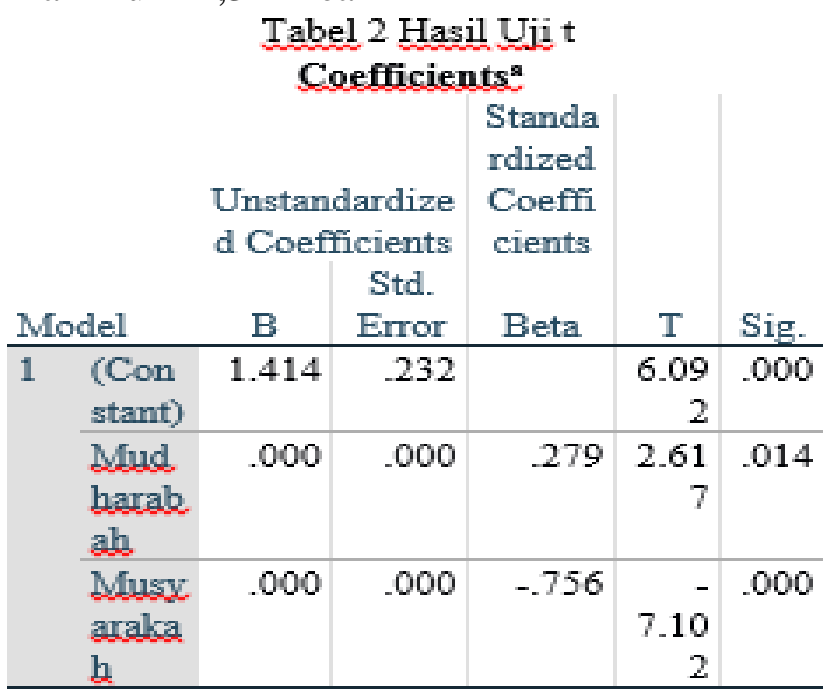

a. Dependent Variable: ROA

Tabel 3 Hasil Uji F

\begin{tabular}{|c|c|c|c|c|c|c|}
\hline \multicolumn{7}{|c|}{ ANQVA } \\
\hline \multirow{2}{*}{\multicolumn{2}{|c|}{ Model }} & Sum of & & & & \\
\hline & & $\begin{array}{c}\text { Square } \\
\mathbf{s}\end{array}$ & df & $\begin{array}{l}\text { Mean } \\
\text { Square }\end{array}$ & F & Sig. \\
\hline 1 & $\begin{array}{l}\text { Regre } \\
\text { ssion }\end{array}$ & 3.589 & 2 & 1.795 & $\begin{array}{r}29.7 \\
00\end{array}$ & .000 \\
\hline & $\begin{array}{l}\text { Resid } \\
\text { ual }\end{array}$ & 1.752 & 29 & .060 & & \\
\hline & Total & 5.341 & 31 & & & \\
\hline
\end{tabular}

a. Dependent Variable: ROA

b. Predictors: (Constant), Musyarakah.

Mudharabah.

\section{Pembiayaan Mudharabah berpengaruh} terhadap Profitabilitas

Diketahui X1 memiliki sig. $0,014<0,05$, t hitung 2,617 > t tabel 2,042. . Maka variabel X1 memiliki pengaruh positif serta signifikan terhadap variabel $\mathrm{Y}$. Hal tersebut menjadi tidak sejalan dengan hasil yang dilakukan oleh Taudlikul Afkar (2017) dimana dalam hasilnya tersebut menerangkan pembiayaan mudharabah tidak memiliki pengaruh terhadap profitabilitas.

\section{Pengaruh Pembiayaan Musyarakah terhadap Profitabilitas}

Diketahui X1 memiliki sig $0,000<0,05, \mathrm{t}$ hitung $-7,102>\mathrm{t}$ tabel 2,042. Maka variabel X2 memiliki pengaruh negative serta signifikan terhadap variabel Y. Hal tersebut menjadi tidak sejalan dengan hasil yang dilakukan oleh Daniel Yusuf, Hamdani dan Kholilul Kholik (2019) dimana dalam hasil temuannya menerangkan pembiayaan musyarakah tidak berpengaruh signifikan terhadap profitabilitas. 
Pengaruh Pembiayaan Mudharabah dan Musyarakah terhadap Profitabilitas

Diketahui variabel X1 dan X2 memiliki sig. $0,000<0,05$. F hitung $29.700>\mathrm{F}$ tabel 4,17, maka hal tersebut bisa dikatakan variabel X1 dan $\mathrm{X} 2$ dengan bersama-sama mempunyai pengaruh positif dan signifikan terhadap variabel Y.

\section{KESIMPULAN}

Diketahui dari hasil temuan serta pembahasan yang telah dilakukan, maka hal ini dapat disimpulkan sebagai berikut: Pertama, variabel X1 (mudharabah) memiliki pengaruh yang positif dan signifikan terhadap variabel $\mathrm{Y}$ (profitabilitas). Kedua, variabel X2 (musyarakah) memiliki pengaruh yang negative dan signifikan terhadap variabel $Y$ (profitabilitas). Ketiga, variabel X1 dan X2 dengan simultan memiliki pengaruh positif dan signifikan terhadap profitabilitas.

\section{DAFTAR PUSTAKA}

Aditya, M. R. (2016). Pengaruh Pembiayaan Mudharabah Dan Pembiayaan Musyarakah Terhadap Tingkat Profitabilitas Bank Umum Syariah Periode 2010-2014. Jurnal Profita, 4(4), 1-11.

Afkar, T. (2017). Influence Analysis Of Mudharabah Financing And Qardh Financing To The Profitability Of Islamic Banking In Indonesia. AJIE - Asian Journal of Innovation and Entrepreneurship, 02(03), 340-351.

Antonio, M. S. (2001). Bank Syariah. Gema Insani.

Arifianto, T., \& Apollo. (2020). Pengaruh Bagi Hasil Pembiayaan Mudharabah Pembiayaan Musyarakah dan Pembiayaan Murabahah Terhadap Profitabilitas. Ilmu Manajemen Terapan, 1(4). https://doi.org/10.31933/JIMT

Arwani, A. (2016). Akuntansi Perbankan Syariah dari Teori ke Praktik. Deepublish.

Aulia, F. U. (2020). Akuntansi Bank Syariah. IAIN Madura Press.
Dyah, A., Martika, L. D., \& Rahmawati, T. (2017). Pengaruh Pembiayaan Mudharabah, Pembiayaan Musyarakah Dan Sewa Ijarah Terhadap Profitabilitas. Jurnal Riset Keuangan Dan Akuntansi, 3(1), 53-68. https://doi.org/10.25134/jrka.v3i1.673

Hasanuddin, M., \& Mubarok, J. (2012). Perkembangan Akad Musyarakah. Kencana.

Hasibuan, F. U. (2019). Analisis Pengaruh Pembiayaan Murabahah, Mudharabah, dan Musyarakah Terhadap Return On Asset Studi Kasus Pada PT Bank Muamalah Indonesia TBK. Periode 2015-2018. Human Falah:, $6(1)$.

Kariyoto. (2017). Analisa Laporan Keuangan. UB Press.

Kasmir. (2012). Manajemen Perbankan Edisi Revisi. Rajawali Press.

Nawawi, A., Nurdiansyah, D. H., \& Al Qodliyah, D. S. A. (2018). Pengaruh Pembiayaan Mudharabah dan Musyarakah Terhadap Profitabilitas (ROA) Pada BPRS HIK Bekasi Kantor Cabang Karawang. FALAH: Jurnal Ekonomi Syariah, 3(2), 96. https://doi.org/10.22219/jes.v3i2.7679

Prihadi, T. (2019). Analisis Laporan Keuangan. Gramedia Pustaka Utama.

Septiana, A. (2019). Analisis Laporan Keuangan. Duta Media Publishing.

Siregar, S. (2017). Metode Pemilihan Kuantitatif. Kencana.

Subakti, T. (2019). Akad Pembiayaan Mudharabah Perspektif Hukum Islam. Literasi Nusantara.

Yentisna, \& Alvian, A. (2019). Pengaruh Pembiayaan Mudharabah dan Musyarakah Terhadap Tingkat Profitabilitas Pada Bank BNI Syariah Tahun 2015-2017. Menara Ilmu, $\operatorname{XIII}(2), 102-114$.

Yusuf, D., Hamdani, \& Kholik, K. (2019). The 
Effect of Buy and Sell Financing (Murabahah), Profit Share Financing (Mudarabah), Equity Capital Financing (Musyarakah) and Non-Performing Financing Ratio on Profitability Level of Sharia
Commercial Banks in North Sumatera. Britain International of Humanities and Social Sciences (BIoHS) Journal, 1(1), 81-88. https://doi.org/10.33258/biarjohs.v1i1.18 